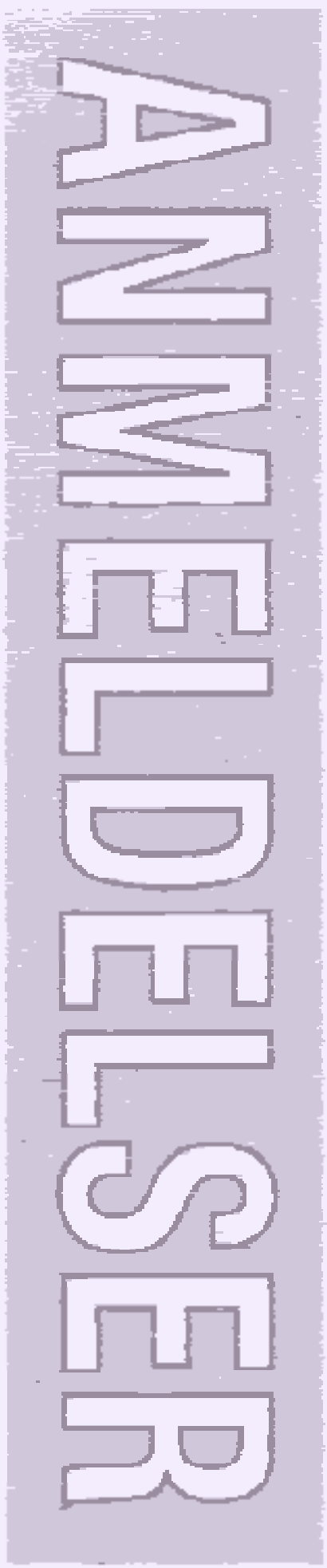

Fan Hong \& J. A. Mangan (Eds.): Soccer, Women, Sexual Liberation. Kicking Off a New Era. London: Frank Cass 2004 (286 sider, ISBN 07-1465509-0).

I den internationale serie om sportsstudier "Sport in the Global Society", redigeret af en af sportshistorikerfagets grand old men - J.A. Mangan, er der netop udkommet en antologi om "damefodbold" (på dansk kaldes den organiserede fodbold for kvinder for "Damefodbold" og ikke kvindefodbold!). Antologien bør absolut hilses velkommen al den stund, at forskningsbaserede artikler, antologier og bøger om dette "idrættens stedbarn" er en mangelvare. Emnet er kun i ringe grad behandlet i dansk (idræts)forskning. Antologien er desuden med til at sætte en ny dagsorden og er dermed med til at sparke en ny æra i gang for damefodbolden.

Bogen er opbygget med en prolog af bogens to redaktører (Fan Hong \& J.A. Mangan) og en epilog af bogens kvindelige redaktør (Fan Hong), der på glimrende vis indrammer de 14 forskellige artikler om damefodbold i forskellige verdensdele og lande. Dertil kommer en introduktionsartikel om Verdensmesterskabet i damefodbold i USA i 1999, skrevet af Donna de Verona. Det er ikke en forskningsbaseret artikel, men den skal videregive nogle vigtige erfaringer omkring afviklingen af et sådant mesterskab og bringer en succeshistorie om "best practice" - om damefodboldens indtog i USA.

Prologen indledes med en karakteristik af kvindernes indtog i den moderne sport, der præges af nedladenhed og konfrontation; fornægtelse og trods; fordømmelse og modstand - og alt for ofte af meget hårde kampe for at få adgang til sportens verden. En karakteristik som desværre alt for let genfindes i antologiens 14 forskellige artikler, hvor forfatterne har undersøgt damefodboldens vilkår i Afrika, Amerika, Asien og Europa.

Damefodboldens historie i denne antologi viser trods alt, at kvinderne kan overvinde massiv modstand, nedladende stereotyper og ondskabsfulde myter og vinde indpas i sportens verden. Selv om der på denne baggrund er basis for at være optimistisk, så gennemsyres artiklerne desværre af en anden mere nedslående tendens. Den globale økonomiske ekspansion revolutionerer vores hverdag på mange områder (også sportens), men uanset hvilket land der undersøges, og uanset om indbyggernes samlede indkomst er faldet, stagneret eller steget, så er kvinder overrepræsenterede blandt taberne og underrepræsenterede blandt vinderne. Redaktørerne ser løsningen på såvel samfundenes som fodboldverdenens vedholdende ødelæggende ulighed som værende afhængig af dels den globale økonomi, statslige politikker og effektiviteten af kvindernes egen organisering. Redaktørerne un- 
derstreger, at kvinderne i fremtiden kun ved at organisere sig vil være i stand til at blive medspillere i såvel den transformerede verdensøkonomi som i en transformeret global fodboldverden. Men modstanden er tung, og det gælder både kommercialiseringen, uligheden og ikke mindst den politiske inerti. Regeringsorganer er nødt til at spille en aktiv rolle i det 21. århundrede for at sikre alle borgere mulighed for at dyrke sport og dermed fremme befolkningernes livskvalitet. Redaktørerne mener, at denne udvikling i "Sport for All“ kun kan fremmes, hvis kvinder i et større omfang bliver hørt - og deltager aktivt $-\mathrm{i}$ beslutningsprocesserne på både nationalt og lokalt niveau.

Afslutningsvis anbefaler antologiens redaktører, at kvinder generelt - og fodboldspillende kvinder i særdeleshed - skal følge den vej, som de amerikanske fodboldkvinder er slået ind på ved at samarbejde med den såkaldte "bevidsthedsindustri", hvor der skabes en symbolsk relation mellem kultur, sport og handel. Der henvises til, at netop de amerikanske kvinder førte an på denne vej i forbindelse med USA's afholdelse af Verdensmesterskabet i damefodbold i 1999. At agere i denne "bevidsthedsindustri" ${ }^{\prime \prime}$, hvor ikke mindst medierne spiller en afgørende rolle, vil efter redaktørernes mening være et middel til at fremme (sports)kvinders rigdom, magt og indflydelse, selv om der i samarbejdet med medierne også lurer store farer. Helt af- gørende er det dog, at de amerikanske kvindelige fodboldspillere nu i langt højere grad er til stede og deltager aktivt i beslutningsprocesserne omkring fodboldspillets fremtid.

Antologiens 14 artikler er skrevet af følgende forskere: USA: af Andrei S. Markovits \& Steven L. Hellerman, Canada: af M. Ann Hall, Kina: af Fan Hong \& J.A. Mangan, Korea: af Eunha Koh, Indien: af Boria Majumdar, Danmark: af Anne Brus \& Else Trangbæk, England: af Jean Williams, det tidligere Østog Vesttyskland: af Gertrud Pfister, Norge: af Kari Fasting, Irland: af Ann Bourke, Sverige: af Jonny Hjelm \& Eva Olofsson, New Zealand: af Barbara Cox \& Shona Thompson, "The Africa Game" Senegal, Nigeria og Sydafrika: af Martha Saavedra samt Brasilien: af Sebastiâo Votre \& Ludmila Mourâo.

Hver for sig fungerer de enkelte artikler godt og giver et godt indblik i damefodbolden i de(t) omtalte land(e). Samlet set får læserne en række grundige, indsigtsfulde og nye informationer omkring såvel damefodboldens udbredelse som dens meget forskellige vilkår i de enkelte lande. Artiklerne er dog præget af meget forskellig opbygning i både struktur og indhold, og der er en stor forskel på vægtning af henholdsvis historiske og/eller sociologiske tilgange, hvilket i høj grad besværliggør et komparativt perspektiv. Den på mange måder interessante og velskrevne danske artikel af Else
Trangbæk og Anne Brus, som jo nok har speciel interesse for danske læsere, skiller sig ud set i et komparativt perspektiv. Dels har denne artikel en mere casestudiebaseret tilgang til emnet end nogle af de øvrige artikler, og dels fører den ikke særligt fyldestgørende det historiske perspektiv op til samtiden og damefodboldens nuværende status i Danmark. Forfatterne skriver godt nok, at deres intention er at skildre dansk damefodbold i perioderne før 1970, 1970-72 og 1972-2000, men især den sidste periode er for overfladisk behandlet. Forfatterne er dog undskyldt af det faktum, at sociologisk forskning om damefodbold er en mangelvare i Danmark, specielt når vi sammenligner med antologiens artikler om damefodbold i nabolandene Sverige, Norge og Tyskland. Til trods for, at komparation generelt er vanskelig for læseren, er det dog bogens fortjeneste, at man på udmærket vis kan uddrage en lang række fælles perspektiver og overordnede problemstillinger på kvinders sports- og fodbolddeltagelse, som det også er gjort i antologiens prolog og epilog.

Epilogen, der på glimrende vis opsamler tendenser og perspektiver fra de 14 artikler, har fået titlen: "Soccer: A World Sport for Women". Titlen indikerer antologiens centrale pointe: at damefodbold har udviklet sig fra at være en marginalsport for kvinder til i dag at være en verdenssport for kvinder. Ifølge Fan Hong har damefodbold på verdensplan gen- 
nemgået en revolution skabt af feministisk aktivisme, glødende nationalisme, politiske ambitioner, sponsorering, statslige politikker og kulturelle forandringer i Nord- og Sydamerika, Asien, Afrika og Australien. Fodbold, som uden tvivl har været en af de største, traditionelle mandlige bastioner samt symbolet på mænds prestige og privilegier, er overgået til at være symbolet på kvindefrigørelse og ligeberettigelse i sporten. Fan Hong mener, at udviklingen i damefodbold symboliserer den moderne feminisme: den har ikke behov for at retfærdiggøre sig, er individualistisk, "empowered" og selvsikker. Trods disse positive toner viser adskillige af antologiens artikler, at damefodbolden stadig møder massive ressourcemæssige problemer fremkaldt af dårlig medieeksponering, mangelfuld sponsorering og den maskuline og patriarkalske organisering $_{\mathbf{z}}$ som hersker i fodboldverdenen. På denne baggrund stiller Fan Hong spørgsmålet: Hvad er fremtiden for damefodbold?

FIFA's (det internationale fodboldforbund) svar på dette spørgsmål er blandt andet, at damefodbolden skal "feminiseres", forstået således, at de kvindelige fodboldspillere skal gøres til sex-objekter for at tiltrække tilskuere, sponsorer og medier! Det er næppe den vej de $_{L}$ kvindelige fodboldspillere ønsker udviklingen skal gå, men hvilke andre muligheder er der så? Fan Hong har henvendt sig til nogle kvindelige forskere og har her fundet svaret, at det er hele sportskulturen (og fodboldkulturen), der skal forandres. Forskerne har forskellige bud på indholdet af disse forandringer. De mest radikale feminister mener, at sporten skal forandres, så kulturen ændres fra konkurrence og aggressioner og hen mod det fælles og det ekspressive. Fan Hong replicerer på denne feministiske utopisme, at forskningen helt og aldeles overser, at også kvinder værdsætter konkurrencer både som deltagere og som tilskuere.

Fra artiklerne kan det konkluderes, at uanset de mange problemer og den megen modstand, som damefodbolden konstant møder, er damefodbold kommet for at blive! Fan Hong mener, at der er tale om tre nutidige trends, som generelt præger sporten: globalisering, kommercialisering og feminisering, og at disse pågående forandringsprocesser har startet en ny æra for damefodbolden på verdensplan. Bogen udkrystalliserer en lang række problematikker omkring sport og køn. Men redaktørernes bemærkning om, at uligheden afhænger af den globale økonomi, de statslige politikker og kvinders deltagelse i de magthavende organisationer, fremstår som det altafgørende argument. Dette forhold ses tydeligt i fodbold, hvor problemet ikke kun ligger i selve sportens aktiviteter, regler og kønsdifferentiering, men snarere $\mathrm{i}$ hele det institutionelle "set-up". Dette konstruerer og fastholder definitionerne af, hvad der er maskulint og feminint i sporten og dermed tildeler damefodbolden en position som marginaliseret og stigmatiseret. Denne position gælder uanset om fodbold betragtes som en kvindesport (i USA) eller betragtes som en mandesport (i Europa). Begge steder har modstanden mod kvindernes indtog været temmelig ensartet og massiv. De statslige politikker rummer, trods internationale trends, ofte også forskelle fra land til land. I Danmark har der på trods af tilslutningen til FN's "Sports for All" deklarationer, $\mathrm{fx}$ ikke været et ønske om at gribe ind i idrætsorganisationernes autonomi for at fremme ligestilling.

Men er der overhovedet et problem med ligestillingen $\mathrm{i}$ idrætsorganisationerne i Danmark, kunne man meget passende spørge?

Ja, desværre står det faktisk temmelig galt til. Som det også ses i en af artiklerne i dette nummer af Dansk Sociologi. Vejen frem må derfor, som det også påpeges i antologien, gå gennem kvindernes deltagelse i idrætsorganisationerne for herigennem at få magt og indflydelse på de fremtidige idrætspolitikker. Denne problematik bør samtidig tages op som et selvstændigt fokusområde i et globalt perspektiv, så det må fremstå som et forslag til tema for en ny antologi i denne udmærkede række af sportsstudieudgivelser.

\section{Laila Ottesen}

Institut for Idræt

Københavns Universitet 
Gertrud Pfister: Frauen und Sport in der DDR. Köln: Sport \& Buch Strauss 2002 (314 sider, ISBN 38-9001368-6).

Ett livligt intresse har fortfarande varit fokuserat på idrottslivet inom det förra DDR, fast staten själv varit historia redan i femton år. Bakom idrottslandets triumfer på olympiska och VMfälten har en skuggsida avslöjats: en del av elitidrottens vardag var också inhumana experiment med människoliv samt ett systematiskt utnyttjande av unga talanger. Tillsvidare har forskningen till nyanser koncentrerat sig kring elitidrotten och dopningssystemet, och i en politisk analys från statsledningen/politbyrån till olika institutioners praktiska opereringsnivå. Huvudsakligen har behandlingen berört det mest synliga - och kanske väntade. Inom kort är det endast graden av förvåning och skandaler som höjs med dessa resultat.

Gertrud Pfister hänvisar i inledningen av sin bok till denna forskning och påpekar, att "vardagen" eller helhetsbilden av idrotten i DDR har förblivit mindre bekant; sådana saker som om man, hur och varför idkade idrott; vilka möjligheter och vilka begränsningar man mötte; hur påverkade idrotts- och samhällssystemen varandra. Kvinnorna var "det starka könet" både inom och utanför idrotten, och deras stora framgångar i elitidrotten var en del av DDR-imagen. Detta resulterade enligt Pfister i en rad sosiologiska forskningar om "Ost-Frauen", men underligt nog tog man inte fram temat "kvinnor och idrott", inte i idrottsforskningen, eller i könsforskningen eller i den såkallade "DDR-forskningen". Dock var det fråga om ett idrottsland, som dessutom kallade sig ett kvinnoemancipationens land, vilket skulle ha bjudit ett givande forskningsfält rörande växelverkan mellan könssystemet, samhälle och idrott.

Författaren själv började intressera sig för ämnet redan på 80-talet, och fick sedan efter "Vändningen" möjligheten att påbörja en forskning med frågor som hon fann relevanta: om kvinnorna i idrotten var "emanciperade", vilka möjligheter idrotts- och könssystemet hade bjudit dem, eller vilken roll de spelade inom idrotten. En tydlig skillnad i erfarenhets- och tankesätten och mönster "mellan väst och öst" blev en realitet när det påbörjade projektet mötte källsituationen. Information om kvinnor måste utgallras ifrån ett massivt allmänt material. Här, och när det gällde t.ex. statistiken, bjöd den i DDR förhärskande "emancipationsdogmen" på likartade svårigheter: när kvinnofrågan var löst, brukade man inte i många ställen fördela numerärt kvinnor och män. Begränsade resurser och bristfällig förhandsforskning var orsaken till att många från kvinnornas synpunkt viktiga sektorer måste utlämnas, såsom skolidrott, lärarutbildning samt tränarutbildningen och de kvinnliga tränarnas arbetsmöjligheter.
Pfister tar fram också vissa forskningsaktuella utgångspunkter. En historisk rekonstruktion av organisationer och institutioner, eller av levnadsförhållanden och vardagsorientering i landet var problematiskt. Pfister hänvisar här också till den aktuella diskussionen om vem som har rätt att skriva DDR's historia, hur man skall utvärdera systemet i DDR politiskt, ekonomiskt och kulturellt; skall man syfta till en systemimmanent presentation, eller tillämpa totalitarismkoncept på tolkningen; vilka teorier och definitioner kan appliceras, bland annat. Resultaten diskuteras i en könsforskningskontext, därvid berörs också frågan om resultatens relevans till DDRsystemet, dock utan att inveckla sig i några allmänna konfrontationer med samhällssystemet (s.11).

Inledningsdelen i boken visar författarens strävan till att "normalisera" forskningen rörande idrotten det förra DDR och föra den från det första, onekligen politiskt orienterade, polemiska skedet till en mera passionsfri riktning, där idrotten och samhället, är möjligt att betraktas som en mångsidig helhet och där de olika aktörernas möjligheter och strävan är av intresse. T. ex. genom att välja intervjuare från förra DDR-området syftade man också till att överskrida förståelsetröskeln mellan de två olika landsdelarna (s. 211-212).

I det hela gäller forskningen den ömsesidiga påverkan och växelverkansprocesser mellan det politiska sy- 
stemet, könsrelationerna och idrott, framförallt breddidrott i DDR. Elitidrotten är mera åsidosatt, men kommer fram t.ex. som en resursfråga: det som riktades till elitkvinnor var "borta" från breddidrotten. Elitkvinnornas framgång blev ideologiskt reducerad till det politiska systemets överlägsenhet, även i hänsyn till kvinnornas allmänna ställning. Kvinnornas möjligheter i idrotten formades av statens idrottspolitik, idrottens konkreta villkor, och kvinnornas vardag i samhället. Kvinnorna arbetade i regel heldag och samtidigt låg familjeansvaret på deras skuldror: denna dubbelbelastning gav troligtvis inte mycken plats till fritidsaktiviteter som idrott. Till könssystemet i DDR hörde, att familjepolitiska åtgärder riktades till kvinnor, så att de kunde upprätthålla familjeansvaret och klara vardagen. Socialpolitiken var alltså inriktad på att stöda ett tvåkönssystem, där en man och en kvinna hade skilda, traditionellt könsmässiga uppgifter och ansvarsområden. (Dock visar man att jämfört med "Väst-Tyskland" var könsfördelningen på arbetsmarknaden mera utbredd i DDR, så att flera kvinnor arbetade på för väst typiska manliga områden.) Idrottssystemet $\mathrm{i}$ DDR var förankrat i skolor och på arbetsplatser. Av intresse var, om "kvinnovänlig"samhällspolitik aktualiserades där, eller inom fritidsidrottens område.

Naturligtvis tas fram jämlikhetspolitiska grundfrågor: I vilken mån deltog kvinnor i idrotten - och vilka blev passiva, och varför? Vilken roll hade idrotten överhuvudtaget i kvinnornas liv? Dessa frågor besvarar forskningen med hjälp av ett till grunden mycket bristfälligt och spritt källmaterial: organisationsprotokoll, statistik som presenteras även i ett informativt bilagematerial fackböcker och -tidskrifter. Till stöd gjordes en mindre innehållsanalys av idrottsreportagen i valda tidningar, och inte minst skaffade man ett brett intervjumaterial rörande 30 kvinnors erfarenheter.

Bakgrundsavsnittet i boken är grundligt och innehåller en presentation av de allmänna könsarrangemangen och -förhållandena i DDR (t.ex. studier, äktenskap, familjepolitik, arbetslivet), samt en mycket tydlig och välskriven historisk analys om hur idrottssystemet $i$ DDR utformades under olika perioder - vilket inte skedde utan konflikter. Därefter presenteras kapitelvis hur kvinnor och idrott -problematiken behandlades i sportlitteraturen; kvinnornas (icke)maktposition i idrottsorganisationen, elitidrott, kvinnoideal och könssegregering, breddidrott, åtgärder för främjande av kvinnoidrott, resurser, media, samt avslutningsvis vardagserfarenheter vilka lyfts fram med hjälp av intervjuer.

I flera sammanhang, t.ex. rörande statistisk och annan information om kvinnornas deltagande i aktivitet och ledning, hamnar en "nordisk" läsare till jämförelser och pejling gentemot motsvarande data rörande de Nordiska länderna. Den viktigaste ramen är nu "idrotts- och kvinnoemancipationsstaten DDR“/ kontra Väst-Tyskland. Om DDR:s centralidrottsorganisation DTSB aldrig hade en kvinnlig ordförande (s. 81), så har inte heller de nordiska "jämlikhetsländerna" Sverige, Norge eller Finland sett sådana, än i dag. Procentuellt är kvinnligt medlemskap i idrottsorganisationerna i Norden högre (kring 40 \% på 90-talet) än det var 1988 i DDR/DTSB (29\%), men här skulle man kanske även beakta olikheten mellan idrottssystemen. Medan idrottsorganisationen i Norden är baserad på en massrörelse, hade DTSB en annorlunda status. Idrottens ideologiska och politiska betydelse i samhället var stor, och DTSB var (även därför) tätt knuten till den politiska organisationen; båda maktfaktorerna ledde till och stödde en ännu kraftigare manlig anslutning.

Jämfört med elitidrotten hade fritidsidrotten betydligt blygsammare resurser, och många avancerade planer på att arrangera icke-tävlingsmässiga idrottsaktiviteter på olika arbetsplatser gick i stöpet till följd av resursbristen. Därom vittnar forskningen med träffande exempel. (s. 166) Skillnaden till t.ex. kvinnorna i nordiska länder (åtminstone Finland) är, att dessa haft möjligheten/varit tvungna att lappa motsvarande bristfälliga idrottsmöjligheter (när även kommunala resurser och faciliteter varit riktade till män och pojkar) med att tillgodogöra "privata marknader": de har 
betalt själva för sin kroppsövning, som danstimmar och ridning, eller har köpt till sig olika trim- och fitnessföretags service. Detta system blev för sin del en överraskning för forna DDR-kvinnor efter "Vändningen".

Forskningen bjuder på en riklig och omfattande presentation och analys om kvinnornas idrottande-och liv - i DDR. Därtill bifogar författaren ställvis sakkuniga deskriptioner av motsvarande utvecklingar på västyska sidan. Någon sammanfattning om skillnader eller gemensamma drag i dessa två länderna ges dock inte. Det ser ut som om könssegregationen i båda länderna varit, i grund och botten, stark och mera eller mindre traditionella kvinnoideal följdes inom idrotten. Undantaget är elitidrott. En intressant skillnad jämfört med "väst" är också att kvinnorna inte blev sexualiserade i idrottsmedia i DDR.

Till skillnaderna kan man kanske räknas att enligt intervjuerna kvinnorna i DDR var nöjda med landets idrottssystem och sina idrottsmöjligheter. (s. 234-235) De intervjuade kritiserade inte systemets elitorientering, eller såg mindre problem i den sneda könsstrukturen av idrottsorganisationen eller kvinnornas frånvaro från maktpositioner. (Dock var alla de intervjuade från Berlin-området, inga röster från landsbygden hördes). Samma gällde faktiskt kvinnornas hänsyn till andra könsomständigheter i DDR-samhället: bristfälliga möjligheter/makt kompenserades av andra vägar, som ännu inte blir syn- liga i denna forskning? Eller - med lite självironi - är det så, att liksom överallt i världen behövs det en feministisk kyss som väcker den nöjt sovande prinsessan? Att feministerna inte kunde närma sig prinsessans vagga, det togs om hand av de politiska, konservativt traditionella kvinnoorganisationerna, såsom Demokratische Frauenbund Deutschlands.

\section{Leena Laine}

Jyväskylä Universitet

Finland

\section{Ilse Hartmann-Tews \& Gertrud Pfister (Eds.): Sport and Women. Social Issues in Interna- tional Perspective. London \& New York: Routledge and ISCPES 2003 (288 sider, ISBN 04-152-4627-X).}

Sport and Woman er den første tverr-kulturelle analysen av kvinnelige idrettskulturer i et globalt perspektiv. Seksten land er med i dette prosjektet: Brasil, Frankrike, Iran, Japan, Kanada, Kina, Kolumbia, Norge, New Zealand, Spania, Storbritannia, Syd-Afrika, Tansania, Tsjekkia, Tyskland og USA. Et viktig kriterium var å inkludere land med ulike sosio-økonomiske, kulturelle og politiske strukturer. Det var også ønskelig å få med land som kunne vise til positive prosesser og resultater om spørsmål om likeverd og likestilling melom kjønnene i idretten.

Forfatterne av de forskjel- lige kapitlene ble anbefalt å ta utgangspunkt i Judith Lorber's forståelse av kjønnete praksiser i samfunnet i $\mathrm{Pa}$ radoxes of gender fra 1994. Målet var å inkludere et vidt spekter av tverr-kulturelle temaer:

- interaksjonen mellom kulturell innflytelse og strukturerte kjønnete hierarkier

- interaksjonen mellom kjønnsordenen på den ene siden og institusjonelle praksiser i idrett og fysisk aktivitet på den andre

- betydningen av sosiale strukturer for kvinners bevegelseskulturer og deres muligheter til å bli med i disse og eventuelt bidra til å forandre strukturene

- betydningen av sosialisering og utdanning for kvinners aktive deltakelse i idrett og fysisk aktivitet

- "gode eksempler"- utfordringer og begrensninger - idrettspolitikk og konsekvenser for individ og idrettsinstitusjoner

Bokas mål og innhold er meget omfattende. Jeg kan bare kommentere noen av temaene i enkelte land. Fokus blir på enkelte grep som ble tatt i relasjoner mellom stat og idrettsorganisasjoner og internt i organisert idrett.

\section{Industrielle/postindu- strielle land: New Zea- land, USA, Norge og Kanada}

New Zealand, USA, Norge og Kanada kan stå som eksempler på land, der statlige ordninger på 1970-og -80-tallet har skapt rom for satsing på kvinneidrett i organisert idrett. Slik sett kan det forstås som et uttrykk for dati- 
dens ideologiske kjønnsspeil i offentlig sektor. En ny "Rekreasjons og Idretts Lov" ble vedtatt av parlamentet i New Zealand i 1973 for å øke internasjonale idrettsmedaljer for begge kjønn. Den meget omtalte "Title IX" så dagens lys i USA i 1972, som et utdannings tillegg til loven om "Sivile Rettigheter" fra 1964. Ifølge denne skulle alle institusjoner som fikk føderale fond sørge for like muligheter for begge kjønn når det gjaldt deltakelse i leik, trening og lik adgang til fasiliteter.

At denne loven om likestilling ble vedtatt, inspirerte datidens idrettskvinner i mange land i nord. Et av dem var Norge. En høring om kvinneidretten i regi Likestillingsrådet i 1984 fikk viktige følger for denne idretten. Norges Idrettsforbund oppnevnte et sentralt kvinneutvalg, som skulle foreslå tiltak for å styrke kvinneidretten i organisasjonen. Fokus i arbeidet var å få gjennomført likestilling når det gjaldt utøvere, ledere og trenere. En konsekvens av arbeidet var vedtak om kjønnskvotering av ledere i organisasjonen i 1987 og i 1990.

"The Canadian Association for the Advancement of Women and Sport and Physical Activity" (CAAWS) ble opprettet i 1981 som en åpen feministisk organisasjon. Det var en kvinneorganisasjon med et radikalt feministisk perspektiv, der idrett for kvinner var et middel og ikke et mål. Det var en viktig forskjell fra for eksempel det norske kvinneutvalget. Her var idrettsaktivitet et mål og ikke et middel. Flere kanadi- ske organisasjoner på provins nivå ble dannet for bl.a. å få med flere kvinner i idrett og fysisk aktivitet. I 1992 ble imidlertid alle henvisninger til feminisme fjernet fra mål og diskusjoner. Her finnes paralleller til Norge. Alt som kunne smake av radikal feminisme forsvant også fra norsk idrettspolitikk, slik den ble skissert, rapportert og diskutert i organisert idrett omtrent på samme tid.

Kvinners muligheter til å drive idrett generelt ser ut til å ha blitt bedre i land der offentlig sektor tok ansvar, mens toppidrett ser ut til å ha blitt bedre i de fleste av de seksten land som er representert i boka. Fysisk aktivitet $\mathrm{i}$ og utenfor utdanningsinstitusjoner ser imidlertid først og fremst ut til å være et gode for innbyggere i industrielle/postindustrielle land.

\section{Land i "sør": Brasil, Ko- lumbia, Iran og Tansania} Idrett i Brasil, Kolombia og Tansania er i dag ikke en del av offentlig sektor, men først og fremst knyttet til kommersielle aktører som handler ut fra maskuline, bedriftsøkonomiske logikker. Det betyr idrett for de øvre sosiale lag og god grobunn for macho praksiser. Da blir det lite rom for satsing på breddeidrett generelt og idrett for kvinner spesielt. I Brasil må medlemmene betale skatt for å være med i en idrettsklubb og i Tansania må en klubb eie en treningsplass for å bli registert og medlemmer betale treningsavgifter.

Brasilske kvinner har deltatt $\mathrm{i}$ idrett og fysisk aktivitet fra 1920. I motsetning til mange vestlige land, som opprinnelig bare hadde konkurranser for menn uten at kvinneklasser eller termen kvinne var nevnt, inneholder idretts-lover i dagens Brasil eksplisitte formuleringer om at kvinner ikke kan delta i enkelte idretter. Det vil jeg kalle for eksplisitt diskriminering imotsetning til implisitt diskriminering, som er mer vanlig.

Selv om en kolumbiansk nasjonal lov fra 1995 gir innbyggere rett til å drive idrett, rekreasjon og fritidsaktiviteter, er realiteten en annen. Denne nasjonale fortellingen er, slik jeg ser det, en elendighetshistorie om idrettskvinner med få unntak. Å gjøre kjønn i Kolumbia er for kvinner å delta i skjønnheterskonkurranser og for menn å spille fotball.

Idrett i Tansania kan stå som et eksempel på et land som gikk fra en sterk offentlig sektor med offentlig støtte til utdanning og helse til et land som i dag styres av nyliberalistiske økonomiske logikker fra slutten av 1980-tallet. Offentlig støtte til kvinnelige utøvere og lag er blitt meget redusert. Den eneste idrettsorganisasjonen for kvinner er Nettball Foreningen, som ble dannet under britisk kolonistyre rundt 1920. I dag er denne organisasjonen reorganisert for begge kjønn. Kvinnelige utøvere og mannlige trenere og ledere dominerer.

Islamske kvinner har sloss for sine sivile rettigheter $i$ ca.100 år. Utdanning for jenter er forbedret, andel kvinnelige studenter økte til en tredel av totalen og kvinner 
fikk stemmerett i 1963. Idag er islamske kvinner, spesielt i Iran, aktive i idrett. Etter den sjiamuslimske revolusjonen i 1981 ble prinsippet om kjønnssegregering gjennomført i hele landet. En Kvinnelig Idrettsorganisasjon ble dannet samme år som en paraplyorganisasjon for ulike kvinnelige idrettsforeninger. I dag finnes kvinneorganisasjoner i syv og tyve idretter. Radio og TV medierer ikke kvinneidrett.

\section{Hva savner jeg i denne interessante boka?}

Som redaktørene påpeker, er det vanskelig å analysere årsaker og virkninger av grepene som er nyttet for å bedre kvinners bevegelseskulturer. Undertegnede savner kvinnelige idrettskulturer i Australia og Russland. Videre, analyser av kvinnebevegelser i den vestlige verden på 1960- og 70-tallet for å forstå grunnlaget for endringer i kvinneidretten i flere land på 1970-80-tallet. Denne anmelderen skulle også ønske å lese en kort oppsummering av nyliberalismens konsekvenser for bl.a. utradering av radikale feministiske perspektiver i enkelte lands idrettspolitikk og lite offentlig ansvar for idrett og fysisk aktivitet spesielt i land i sør. En analyse av konsekvenser av at globale kommersielle TV-nettverk dominerer mediene i svært mange land hadde også vært ønskelig. Vi vet at de tenderer til å mediere kvinner og menn på en stereotyp måte. Den iranske strategien for å møte denne trenden er å gjøre kvinneidretten usynlig. Det kan forstås som et ekstremt grep for å konsolidere en kultur. Hvis vi skal kunne forstå kvinneidrettskulturer bedre, trenger vi flere bakgrunnstatestikker over kvinners levekår og livsløp. Disse er vanskelige å sammenlikne mellom ulike land. Kanskje dette kan være en strategi for den neste boka om kvinners bevegelseskulturer i en global verden?

\section{Avsluttende bemerk- ninger}

Målet med denne boka var meget dristig og omfattende. Det er kanskje typisk for kvinner at en tør å gripe fatt i slike vanskelige prosjekter. Likevel, synes jeg at forfatterne har lykkes i å lage en meget interessant oversikt over kvinners bevegelseskulturer i seksten land. Boka bør finne sin plass i biblioteker og på websider på skoler, høyskoler og universiteter over hele verden.

\section{Gerd von der Lippe}

Høgskolen i Telemark, Bø, Norge.

\section{Dong Jinxia: Women, Sport and Society in Modern China - Holding Up More than Half the Sky. London: Frank Cass Publishers 2003 (357 sider, ISBN 07-146- 8214-4).}

Ved de olympiske lege i Atlanta i 1996 udgjorde de kvindelige udøvere $35 \%$ af det samlede antal aktive deltagere. I den kinesiske delega- tion var forholdet omvendt, hér var der $65 \%$ kvindelige udøvere og $35 \%$ mandlige. Dette illustrerer meget godt den helt specielle satsning på kvindelige eliteudøvere, der har været i Kina, og som har medført, at det er kvinderne, der bærer mere end halvdelen af medaljerne hjem fra OL. Det gælder især sportsgrene som sportsgymnastik, udspring, bordtennis, skydning, volleyball, badminton, vægtløftning, kapgang, langdistanceløb og svømning.

Hvad er forklaringen bag den kinesiske kvindes udvikling fra en fodindbunden krøbling til en stjernestøvs omspunden eliteudøver på sportens verdensscene? Det undersøger Dong Jinxia i bogen Women, Sport and Society in Modern China. Dong Jinxia, der selv er tidligere elitegymnast og træner, har skrevet bogen $i$ forbindelse med sin ph.d. afhandling. En hovedtese i bogen er, at historien, de sociale, økonomiske og politiske forhold gensidigt spiller ind i skabelsen af disse elitekvinder, og det er dette gensidige og indbyrdes forhold, afhandlingen undersøger. Bogen er samtidig et opgør med vestlige etnocentriske sportsanalyser af Østen. Således medierer hun skellet mellem Øst og Vest, fordi hun formidler i et vestligt sprog, men selv er kinesisk. Man kan sige, at hendes øjne er kinesiske og hendes mund engelsk.

\section{Fra 1949 til 1998}

Bogen fører os med gennem op- og nedture i en tidsperiode med rivende økonomiske og kulturelle forandrin- 
ger, katastrofale og hensynsløse politiske satsninger og deraf følgende tilbageskridt, og mentale omstillinger af enorme dimensioner $i$ verdens folkerigeste nation. $\mathrm{Vi}$ følger således historiens gang fra 1949 til 1998 gennem den særlige optik, som de kinesiske kvindelige eliteudøvere udgør. Dong Jinxia giver, gennem en mangfoldig og omfattende analyse, en brokade af forklaringer på disse kvinders succes. Bogen er inddelt i 5 tidsperioder: De tidlige år omkring kommunismens overtagelse i 1949, perioden omkring "The Great Leap forward" 1957-1965, årene omkring kulturrevolutionen 1966-1976, de økonomiske reformers år 19771989, og årene omkring overgangen til markedsøkonomi 1990-1998. Endvidere indeholder bogen nogle emnesnit: Doping, tre casestudier, forholdet mellem social mobilitet og sportskarriere samt kønsroller inden for elitesporten i det moderne Kina.

Hvem kunne finde bogen læseværdig? Alle, der interesserer sig for kønsroller, ligestilling, udviklingen i det moderne Kina, kvinder og sport, sport og elitesystemer - og så naturligvis en kombination af ovenstående temaer.

\section{En matrix af forklaringer} Bogen fremtrækker mange og meget fintmaskede forklaringer på, hvilke samspil der har gjort sig gældende for de kinesiske kvindelige eliteudøveres store succes og hvorfor. Blandt forklaringerne kan for det første næv- nes, at kvinderne allerede fra begyndelsen af sportens udbredelse i Kina, var aktive. Derfor var de kinesiske kvinder ikke, som deres mandlige kollegaer, fra starten bagud i forhold til deres vesterlandske konkurrenter. Hos de vesterlandske konkurrenter kom kvinderne først meget senere på banen i mange af OL-disciplinerne. For det andet var der et fælles kinesisk ønske om at genvinde national selvrespekt gennem internationale sportssejre. For det tredje indeholdt Kulturrevolutionen en massiv propaganda for ligestilling. For det fjerde var der tale om en stærk central styring og satsning på elitesport samt finansiel opbakning i de perioder, hvor nationaløkonomien ikke lå underdrejet. For det femte blev der etableret en statslig OL-satsning midt i 1980'erne, men allerede tidligere var sportsgrene, som var på OL-programmet, blevet valgt ud som særlige satsningsområder. For det sjette anvendtes der mandlige sparringspartnere til de kvindelige udøvere. For det syvende fandtes der centralt et ønske om at føre storpolitik på de internationale sportsarenaer, og så selvfølgelig som det ottende: dopingspøgelset, som Dong Jinxia i øvrigt forsøger at nedtone. Som sagt er bogens analyser og beskrivelser meget omfattende og modigt modsætningsfyldte, hvorfor denne korte gengivelse ikke yder hendes arbejde fuld retfærdighed.

Bogen er skrevet, så hvert kapitel kan læses for sig. Dette er en stor gevinst, især hvis man kun er interesseret i enkelte af bogens perioder eller temaer, men det giver en del gentagelser. Bogen er meget veldokumenteret og har et omfattende noteapparat, som er placeret bagest $i$ bogen. Noterne i sig selv udgør omkring en tredjedel af bogens samlede sideantal.

\section{Det skabende køn}

Dong Jinxia lægger sig i kølvandet på en socialkonstruktivistisk kønsforskningstradition og ser forholdet mellem køn, sport og samfund som værende under stadig konstruktion, dekonstruktion og rekonstruktion. Dong Jinxia mener, at de fremtrædende elitesportskvinder befinder sig i et vekselvirkende felt, hvor de på den ene side skaber fortællingen om en anden kønsrolle end den eksisterende, samtidig med at de er under indflydelse af det omgivende samfunds kønsroller. Dong Jinxia får dog også frem, at det, at de kinesiske kvindelige eliteudøvere er ligestillet - og på nogle punkter endda mere end ligestillet - med deres mandlige kollegaer, ikke er ensbetydende med, at der er ligestilling i samfundet som helhed. Det fremhæves også, at denne ligestilling blandt eliteudøvere kun gør sig gældende på udøverniveau og ikke på træner- og lederniveau, hvor der i dag stadig er en stor overvægt af mænd.

En af bogens centrale pointer, fremsat i et typisk kinesisk billedsprog, er, at kvinder kan løfte mere end halvdelen af himlen. De kvindelige eliteudøvere er et eksempel herpå. Hvad bogen aldrig 
rigtigt diskuterer er, om det er særlig sundt eller særlig givende, at kvinder lofter mere end halvdelen af himlen. Er det f.eks. ønskværdigt, at kvinderne har dobbelte karrierer; både karrieren, der knytter sig til hjemmet og moderskabet, og den, der knytter sig til arbejdet uden for hjemmet? Svaret er tilsyneladende et ja. Det er lige præcis det, det er for disse eliteudøvere, og glorværdige er deres resultater.

\section{Den manglende sports- kritik}

Dong Jinxia rejser ikke nogen egentlig sportskritik, selvom hun berører den stærke kommercialisering og doping inden for moderne sport. Dong Jinxia diskuterer således ikke noget alternativ til den moderne elitesport og dens bagsider. For medaljen har jo ofte en bagside, f.eks. familiære afsavn, invaliderende sportsskader, manglende livsindhold efter endt sportskarriere osv. Dette til trods for, at Kina faktisk har en ældgammel og finkultiveret bevægelseskultur, som godt kunne tale op imod den moderne sport på en spændende og givende måde. Når dette er sagt, skal det samtidig fremhæves, at jeg finder bogen meget anbefalelsesværdig.

Dong Jinxia har med bogen lavet et historisk snit, hvor hun undersøger dén særlige vinkel på historien, som de kinesiske kvindelige eliteudøvere udgør. På denne måde bliver bogen ikke alene en spændende og fængslende fortælling om kvinder i et helt særligt elite- sportssystem, men også en rigtig god indføring i Kinas moderne historie.

\section{Christine Mønsted}

Cand. Scient. i humanistisk og samfundsvidenskabelig idrætsteori

\section{J.A.Mangan \& Fan Hong (Eds.): Freeing the Female Body: In- spirational Icons. London, Portland: Frank Cass 2001 (268 sider, ISBN 07-146-5088-9).}

Bogen Freeing the Female Bo$d y$ : Inspirational Icons, redigeret af J.A.Mangan og Fan Hong, præsenterer 10 biografiske fortællinger om en række usædvanlige kvindelige sportsudøvere, som alle har været mønsterbrydere i deres måde at dyrke idræt på og desuden har haft afgørende både politisk og samfundsmæssig betydning for udviklingen af kvinders mulighed for at dyrke sport på lige fod med mænd. Det er fortællinger om sportens betydning som globalt fænomen og også om sporten som middel til at hjælpe i kvindernes kamp for ligestilling i sportens verden - og om sportslige værdier som viljestyrke, udholdenhed og stædighed som midler til at åbne for forandring af normer og forestillinger om, hvad der er muligt, passende og ønskeligt for kvinder.

\section{Sportens paradigmer og betydninger}

Bogen fortæller om sportens kropssyn og forståelse af kvindekroppens frigørelse. Den stiller ikke spørgsmål ved sportens kropssyn, værdier og praksisformer som så, men ser dem tværtimod som væsentlige for kvindernes emancipation. Bogen peger i introduktionen på den vestlige forståelse af sporten som udspændt mellem arbejde og leg, men der fortælles primært om sporten som kamp og konkurrence her med kvindelige helte som forbilleder af flid, talent og viljekraft til at blive den bedste. Der skelnes ikke mellem "playing"og "gaming". Selv om både leg og spil har mange ligheder; begge kan lægge op til spontanitet, kraft og viljestyrke samt krav om særlige færdigheder; men legen er ikke rettet mod et ydre praktisk formål. Legen er i princippet fri til at eksperimentere både med motiv, form og udtryk. Den afgørende forskel ligger i valget af motiv for bevægelsen. Hvor frit kan motivet være? Hvor fri kan formen være?

Sportens vægtning af "en tab-og-vind" kode som motiverende faktor er afgørende for, hvilken slags krop der kommer til udfoldelse. Sporten er med sin prioritering af "tab-og-vind" koden i fuld overensstemmelse med vestlige moralske arbejdsnormer om disciplin, sved, hårdt arbejde og at underkaste sig regler. Bogens fortællinger inspirerer til en refleksion over følgende spørgsmål: Hvad betyder det for kropsidealer og normer? Hvad betyder det for femininitet og maskulinitet? Og er der andre måder at arbejde med kroppens fantasi og kraft, 
som også kunne være frigørende? Og er det så en anden slags frigørelse? Hvad betyder det for dannelse af subjektivitet og samfundsstrukturer?

\section{Picassos forsidebillede}

Forsidens stærke Picassomaleri af to kvinder, der løber med hinanden i hænderne langs en strand, udtrykker i billedform en særlig forståelse af kvindekroppens frigørelse. Det er et billede, der fortæller om retten til frodighed og bevægelse som skabende udtryk for øjeblikket; som berusende sansning af rytme, form og farve - en fortælling, der måske fremhæver andre mulige aspekter af (kvinde)kroppens frigørelse. Måske er ligeværd også retten til forskellighed og fri kommunikation og udtryk, som legen og kunsten åbner for? Forsiden kan læses som en fortælling om bevægelse som et sanseligt møde, der åbner for samsvingen i en fælles strøm af forskelle i form, oplevelse og udtryk som et væsentligt aspekt af livets, legens og frigørelsens mulighed.

\section{Sportens helte- fortællinger og kropssyn} Bogen fortæller om kvinder som helte i sportens verden, men samtidigt også om sportens socialisering af eneren, der både lever op til sportens disciplinære og tekniske kraft på højeste niveauer. Bogen åbner dermed til en refleksion over krop, sport, køn, samfund og livssyn. Her ses tydeligt sportens fortælling om retfærdighed som ensartethed, samme regler og samme bevægelsesformer. Men rummer sporten ikke også et musisk-æstetisk paradigme som udforskning og leg med form og udtryk? Muligheder, der udfoldes i en gensidig, skabende bevægelse af oplevelse, fantasi, skønhed, styrke, forskellighed og mangfoldighed.

Sportens kvinde- og kropsfrigørelse er i bogen primært retten til og muligheden for at træne fysisk hårdt på samme vilkår som mænd og dermed opnå faglig og politisk ligestilling. Der er der selvfølgelig ingen, der kan være uenig i, men kroppen er også vores vigtigste medium til at forbinde os sansende, oplevende og handlende med verden og må derfor også altid forstås ud fra en etisk-æstetisk-eksistentiel dimension, idet æstetisk skal forstås som almene strukturer af kropslighed og sensitivitet og ikke elitært og normativt.

\section{Kropslig handling og oplevelse}

Bogens konklusion er i stærk sammentrængt form: at hvis kvinder vil dyrke sport på lige vilkår og betingelser med mænd, skal de ikke blot være dygtige rent sportsligt, men også være vedholdende og viljestærke, hvad angår at arbejde administrativt og politisk bevidst. Hvis de er det og kobler det sammen med støtte fra familie og venner og en aldrig vaklende målrettethed og udholdenhed, ja, så kan de bryde igennem samfundsforestillinger og normer om, hvad der er passende og rigtigt for kvinder. De bliver ikoner; sportens mønsterbrydere ses i rela- tion mand-kvinde lighed.

Her i 2004 er det måske en indlysende fortælling og stadigvæk en nødvendig fortælling; men måske skal fortællingen udvides med sportens mulighed for at være medie for at udforske bevægelsens som erfaringens rum for andre betydningsmuligheder, nemlig som skaber og formidler af oplevelse, virkelighed og livslyst, som et rum for samhørighed og gensidighed i møder af forskellighed og kropslig kreativitet; sådan som $\mathrm{fx}$ O. Christensen skriver i sin glimrende artikel "The Playing Collective. Snowboarding, Youth Culture and the Desire for Excitement" i Ethnologica Scandinavica (1999), og som V. Kondos fortæller i sin artikel "Fire, Heroes and the Cosmic: Aesthetic Resonances of Fire-walking in Northern Greece" i The Australian Journal of Anthropology fra 2000.

\section{Til videre inspiration}

Bogen tager i epilogen højde for en række forbehold og problemer i relation til den biografiske metode og faren for en for forenklet fortolkning. Selv om bogens fortællinger ikke direkte stiller spørgsmålstegn ved sportens traditionelle konkurrenceparadigme, åbner og inspirerer den til refleksion og videre udforskning af de store og vanskelige spørgsmål og begreber, som allerede forsiden og titlen åbner med både i billed og i ord. Hvad forstår vi ved kroppen? Hvad forstår vi ved kvindekroppen? Hvad forstår vi som frigørelse? Og frigørelse af kvin- 
dekroppen noget andet end frigørelse af mandekroppen? Er sportens kropsfortællinger kun for helte? Eller har sporten også en poetisk dimension?

\section{Lis Engel}

Institut for Idræt

Københavns Universitet

\section{Anne Bolin \& Jane Granskog (Eds.): Athletic Intruders: Ethnographic Re- search on Women, Culture, and Exerci- se. Albany NY: State University of New York Press 2003 (294 sider, ISBN 07-914-5583-1).}

Antologien Athletic Intruders er redigeret af to amerikanske antropologer, Anne Bolin og Jane Granskog, der begge er aktive feminister og eliteatleter inden for henholdsvis bodybuilding og triatlon. Med bogen undersøger de "kvinders plads i sport og motion" via sociokulturelle tilgange hentet fra sportsantropologi, sportssociologi og feministstudier. Med ni casestudier baseret på etnografisk feltarbejde, bidrager antologien til det voksende korpus af etnografiske studier af kvinder, køn, sport og motion. Titlen peger endvidere på bogens fokus på de konflikter og modsætninger, kvinder oplever som atleter, når de trænger ind på mandsdominerede idrætsarenaer, der usynliggør, marginaliserer eller ekskluderer dem.

Antologien dyrker en kon- struktivistisk tilgang, der tager afstand fra biologisk essentialisering og udfordrer strukturel determinisme. Bolin og Granskog fremhæver især antropologiens erfaringsnære analyser som en tiltrængt nuancering af kulturstudiernes analyser af strukturelle og ideologiske aspekter af samfundsmæssige magtrelationer, der manifesteres i sport. De ønsker at fremme ligestilling ved at udforske, hvordan kvinder tilegner sig, udfordrer og transcenderer hæmmende "patriarkalske strukturer" og mandsdominans i forskellige idrætsarenaer. I følge Bolin og Granskog styrker bogen feministiske studier ved at belyse de somatiske erfaringer og selvforståelser, der gennem deltagelse $\mathrm{i}$ sport indvirker på kvindernes liv og herigennem transformerer de kulturelle kontekster, i hvilke de indgår.

\section{Insider studier}

Bolin og Granskogs indledende oversigtsartikel redegør for en "refleksiv" etnografisk tilgang til studier af kvinder og sportsaktiviteter. Denne "dialogiske antropologi“ omskriver informanter til "konsulenter" eller "feltfæller", der i lighed og fællesskab med forskeren medproducerer data. Bolin og Granskog lægger vægt på forskerens "insider" erfaringer som medlem af samme køn og idrætslige subkulturer, som de undersøgte. Forskeren positioneres således ikke som udefrakommende observatør, men som kompetent deltager i feltets aktiviteter og socialt liv.
Hertil følger ni case-studier af meget forskellig kvalitet. Der gøres en dyd ud af at definere "sport" bredt for at omfatte artikler, der handler om kvinders deltagelse i konkurrencesport som triatlon, basketball, bodybuilding, softball og rugby, i motionsaktiviteter som aerobic, styrketræning og jogging samt i fritids motorcykelkørsel.

Bolin og Granskog udpeger kvindernes somatiske erfaringer og sportsdeltagelsens indflydelse på deres liv som gennemgående temaer, der forbinder artiklerne. Mens dette tema er centralt placeret i Granskogs og til dels i Bolins bidrag, har de fleste bidragsydere andet på hjerte. Et mere gennemgående tema er således, hvordan kvinder forholder sig til normative kropsbilleder og forestillinger om, hvad kvinder kan og bør tillade sig at have af kropslige dimensioner og dyrke af fysisk aktivitet for både at opretholde og udfordre egen og andres opfattelser af dem som kvinder.

Generelt konkluderes der, at kvinder, der dyrker sport, forhandler og forvalter køn ved at balancere mellem at tilpasse sig og modsætte sig normative kropsbilleder og påbud om en bestemt praksis.

Markulas artikel "Postmodern Aerobics: Contradiction and Resistance" repræsenterer denne genre, men i modsætning til flere andre bidrag, går den ud over denne ramme. Markula påpeger, at nye forståelser af magtrelationernes kompleksitet og van- 
skelighederne med definitivt at udpege magtkilder må nødvendigvis lede til klarere definitioner af, hvori individers modstand og empowerment ligger. Endvidere må magtens kompleksitet anspore til mere sofistikerede forståelser af sport som "sites of resistance" og kulturelle ændringer, der fremmer ligestilling.

\section{Konteksten, der blev væk}

Med to undtagelser omhandler case-studierne kvinder, sport og motion i USA. Èn undtagelse er Davis' velskrevne artikel om slankekure og motion, der kommer og forsvinder i en fiskerby $i$ Canadas østligste provins, Newfoundland. Den anden undtagelse, der desuden er skrevet af bogens ene mandlige bidragyder, omhandler elite amatørkvinderugby i Wales. Forfatteren Howe situerer kvinderugby i relation til rugby som walesisk national sport, der samtidigt dyrkes som et eksklusivt ritualiseret mandedomæne.

På trods af Bolins og Granskogs forsikringer om, at en etnografisk tilgang belyser individuelle kvinders erfaringer med at navigere i kulturelle landskaber og i forhold til institutionelle rammesætninger, tegnes rammerne uhyre svagt $i$ artiklerne, der vedrører USA. Landets ellers ret sammensatte institutioner og kulturer tages for givet. I flere artikler må læseren gætte, i hvilket kulturelt landskab og i hvilke institutionelle rammer handlingen foregår. Selv hvor artiklens "lokus" udpeges, ikoniseres den som $\mathrm{fx}$ "det triatletiske fællesskab", "postmoderne kultur", "vesten", eller "det lokale fitnesscenter". I den mest kitschede artikel om kvinder og motorcykler, der af sprogmæssige og analytiske grunde ikke hører hjemme $\mathrm{i}$ antologien, havner læseren i "Det Generelle Amerikanske Samfund" med store bogstaver.

Informanterne eller "konsulenterne" befinder sig således ofte i og i opposition til "mainstream", "middelklassen", og "vestlige paradigmer for femininitet", hvorfra deres individuelle stemme synes at repræsentere en universel kvinde. At gøre diverse amerikanske kvinder, der dyrker sport og motion, til hovedrolleindehavere af kvindedommen på vegne af "alle vestlige kvinder" er en aldeles problematisk kontekstualisering.

Kun én artikel problematiserer amerikanske race- og etniske forhold ved at undersøge betingelsesmuligheder for kulturelle udtryk blandt afro-amerikanske universitetsatleter. Strattas interessante, men ufærdige analyse af, hvordan forholdet mellem antal af sorte og hvide på et hold påvirker holdets socialitet, situeres på et universitet, der betegnes ikonisk som PWI (Predominantly White Institution). Som om dette forhold siger alt om rammerne for både de sorte og hvide atleters livsvilkår. Indforståethed fortsætter i Faye Wachs ellers interessante og velargumenterede artikel om kønspositionering i "co-ed softball", der tager læserens kendskab til spillets positioner og regler for givet.

\section{Etnografisk tilgang under udvikling}

På trods af dens få velskrevne og velargumenterede artikler, lever antologiens ujævne analyser ikke op til redaktørernes metodologiske og teoretiske ambitioner. Det lykkes ikke overbevisende at tematisere og belyse kvinders somatiske erfaringer, der i nogle bidrag mere blot er slået fast end vist og $i$ andre slet ikke problematiseret. Med ambitionen om at dyrke en refleksiv, etnografisk tilgang er det også mærkværdigt, at der slet ingen henvisninger er til Brownells velkendte etnografi om egen deltagelse i atletik på universitetet i Beijng, Kohns analyser af egen erfaringer med aikido eller Pinks arbejde med kvindetyrefægtere. En del af artiklerne er skrevet $i$ et upræcist og forceret sprog, som om det var muligt at skubbe en flagrende empiri på plads ved både snirklede og emfatiske gentagelser af manifestagtige teoretiske og ideologiske klicheer. Endvidere udviser tre forfattere et afslappet forhold til henvisningskunsten ved at angive kilder, der ikke bruges i teksten.

Med disse forbehold kan bogen alligevel anbefales som et forsøg på at skubbe diskussioner inden for feministiske studier af kvinder, køn og sport videre via etnografiske analyser, med vægt på forskerens egne langtidserfaringer i det felt hun undersøger. Selvom analytiske fordele ved insiderens kend- 
skab til feltet ofte overtrumfes af indforståethed, der selvfølgeliggør og udvisker konteksten, problematiserer artiklerne ["the "doing" of "being"“] de performative aspekter af det at være en fysisk aktiv kvinde i mange forskellige miljøer. Bogens fokus på kroppen, kropslige handlinger og interaktion viser tydeligt det analytisk uproduktive i at opretholde reproduktion og modstand som modpoler (med kompromis som en middelvej). Begreber som reproduktion, modstand og kompromis formår ikke at fastholde og ordne verden, lige netop fordi de er kropslige genrer, der trækkes på, spilles ud og kommunikeres nuanceret $\mathrm{i}$ handling.

\section{Sally Anderson}

Institut for Antropologi Københavns Universitet

\section{Lis Højgaard \& Dorte Marie Søndergaard (red.): Akademisk tilblivel- se. Akademia og dens kønnede befolk- ning. Kobenhavn: Aka- demisk Forlag (240 sider, ISBN 87-500-3764-1).}

At læse bogen "Akademisk tilblivelse. Akademia og dens kønnede befolkning" er en interessant og udviklende affære. Redaktørerne, der selv har leveret bidrag, skriver indledningsvist, at man igennem forskellige tilgange har søgt at vise kvinders muligheder i akademia. Hvert enkelt bidrag indeholder såle- des ikke nødvendigvis både et mikro og et makro perspektiv, men i løbet af læsningen af de forskellige bidrag stykkes mikro og makro, struktur og individ sammen i en helhed, der lader en forstå, at kønnet fortsat er på spil i akademia trods forestillingen om det modsatte. Styrken i at lade mange tilgange belyse det samme emne understøttes af, at der generelt i bogen er mange eksempler på, at man refererer til hinandens pointer og tekster. Såvel ligheder som forskelle kommenteres på tværs af tekster, hvilket gør bogen levende og får de enkelte forfatteres pointer til at stå mere klart.

Redaktørerne angiver at bogen er kommet i stand som et mangeårigt samarbejde omkring køn som tema, og at megen inspiration og mange ideer skal tilskrives nordiske kolleger. I praksis er det nordiske sammenlignende perspektiv dog meget underbetonet i de forskellige bidrag. Der er f.eks. kun bidrag fra danske forskere. Hist eller pist dukker tal fra Finland eller Norge op, og af og til falder der et ord om, at tilstandene i Danmark ikke er udtryk for den eneste måde, kvinder og mænds forhold i akademia kan tænkes på. Men det er kun i små mængder, og der er langt imellem disse nordiske sammenligninger. Jeg ved heller ikke, om man virkelig mangler det, men da det nordiske samarbejde nu specifikt nævnes i indledningen, tog jeg mig alligevel $i$ at sidde og kigge efter det. Noget andet slående er, at alle bidragene er af kvindelige forskere. Uanset at man rent sprogligt er gået bort fra at tale om kvinder til i stedet at tale om køn og således omfatte såvel det mandlige som det kvindelige, er det alligevel kvinder, der her - som i så mange andre sammenhænge, blandt andet i herværende temanummer - interesserer sig mest for emnet og skriver om det. De enkelte indlæg omhandler både kvinder og mænd - det mandlige og kvindelige, men problemstillingerne er kvindeligt kønnede, forstået som de barrierer kvinder oplever i akademia. Uden at kende meget til, om der er specifikke barrierer for mænd i akademia og i så fald hvilke barrierer, der er tale om, er det alligevel påfaldende, at denne dimension nærmest er helt fraværende.

Udgangspunktet for bogen er at forklare og belyse, dels hvor mange kvinder der er i akademia samt udviklingen i antallet af kvindelige fastansatte forskere på alle niveauer. Dels hvordan forskere i akademia skabes og italesættes, samt hvilke muligheder det giver kvinderne. Bogen består af otte kapitler foruden forord, og jeg vil her koncentrere mig om 6 af kapitlerne. Efter det indledende kapitel om akademisk tilblivelse af de to redaktører følger et kvantitativt funderet kapitel af Inge Henningsen. Ved hjælp af en række statistikker søger hun at vurdere, hvorvidt ændringer - eller snarere manglen på samme - $i$ andelen af kvinder i akademia skyldes systematisk frasortering af kvin- 
der, eller om der i stedet er tale om et efterslæb, hvor en lav andel af kvinder gennem tiderne fortsat har konsekvenser for, hvor mange professorer, lektorer osv. der er ansat og ansættes. Pointen er, at kvinder fortsat ansættes i langt mindre tal end mænd, uanset at andelen af kvindelige studerende er steget markant. Faktisk er kvinder relativt dårligere repræsenteret $i$ akademia i dag end i 1970'erne set i forhold til andelen af kvindelige studerende. Dengang var forholdet 0,86 . I dag - 30 år senere er forholdet 0,39. En forklaring herpå kan være, at der $\mathrm{i}$ 70 'erne var en stor tilgang af studerende hvilket medførte en række nyansættelser af videnskabeligt personale. Der var altså tale om store strukturelle ændringer. Den store efterspørgsel på akademisk uddannede personer åbnede muligheder for, at kvinderne kunne få ansættelse på universiteterne. Siden er denne udvikling stagneret, og det er Inge Henningsens konklusion, såvel som mange andre af bidragyderne, at en væsentlig øgning af kvinders andel i akademia sandsynligvis vil kræve nye, store strukturelle ændringer. Forklaringen om policywindows lyder tilforladelig og underbygges glimrende af data. Det er ganske vist ikke alt det tabelmateriale, der fremlægges, der lige godt formår at overbevise om, hvorvidt det ikke alligevel er efterslæb ${ }_{\iota}$ der er en vigtig forklaring på, at færre kvinder er ansat $\mathrm{i}$ akademia. I en tabel er der endvidere byttet om på kvinder og mænd, hvilket gør læsningen af den problematisk. Alt i alt er der dog tale om en solid gennemgang af talmateriale og placeringen af kapitlet som et af de første, rummer ydermere den fordel, at man som læser klædes lidt på i forhold til de følgende bidrag, der på forskellig vis søger forklaringer på, hvorfor det strukturelle ser ud, som det gør.

Pointen om, at andelen af kvinder ikke nødvendigvis stiger automatisk med tiden, genfindes i Hanne Nexø Jensens bidrag, der tager udgangspunkt i ph.d. studerende. Ud fra tanken om "the leaking pipeline" viser hun, at på trods af det faktum, at der uddannes stort set lige stort mange mænd og kvinder i akademia, er det i højere grad mændene, der får ansættelse som ph.d. stipendiater og dernæst forholdsvis flere af dem, der ansættes som adjunkter. Gennem et større statistisk materiale opstilles forskellige veje, de studerende kan vælge for at komme ind på ph.d. studiet, og hvilke forskellige karriereønsker de forskellige veje efterfølgende giver de studerende. Bidraget er sådan set spændende, men talmaterialet er ikke brugt overbevisende. De tabeller, der vises, er svære at gennemskue, og de interessante tal, der refereres $i$ artiklen, er omvendt ikke altid stillet overskueligt op i tabeller.

Et af de mest interessante bidrag leveres af Charlotte Bloch, der udfra en analyse af følelser hos henholdsvis kvinder og mænd giver et bil- lede af, hvordan vi positionerer os og positioneres, og hvilken betydning det får for kvinder i forskningen. Velargumenteret og velskrivende opruller Bloch først det teoretiske grundlag, hvorefter hun udfra et stort kvalitativt materiale - indsamlet blandt kvindelige og mandlige forskere - viser hvorledes de fire følelsesgrupper; stolthed, vrede, skam og latter, bringes i anvendelse på forskellig vis og får forskellig betydning for mænd og kvinder. Bloch argumenterer overbevisende for, at kvinders strategi ofte fører til socialt tab og dernæst til forringede chancer for karrieren. I forhold til de tidligere strukturelt fokuserede kapitler er der her tale om et individorienteret bidrag, der på meget fin vis understreger og nuancerer en række af de samme forhold, som de øvige indlæg har berørt. Blochs bidrag er veldisponeret og giver en række vigtige og anderledes redskaber til at forstå den forskel, der bliver mellem de to køn i akademia. Samtidig er forskellene så genkendelige, at man fristes til at tænke, hvordan det nogensinde skal blive anderledes, og det giver Bloch ikke rigtig svar på. Sit store materiale til trods får man ikke noget bud på, om yngre og ældre forskere reagerer forskelligt, men da man kan se, hvor rigide tingene ser ud til at fungere på mere overordnet plan, ender man næsten med at være helt lettet over ikke at blive konfronteret med det, der formodentlig er et negativt fremtidsperspektiv. 
Et andet meget velskrevet bidrag leveres af Catherine Hasse, der som den eneste eksplicit beskæftiger sig med studerende. Gennem et år har Hasse fulgt 17 fysikstuderende og derigennem erfaret, hvorledes kvinderne går fra at have lige så stor faglig selvsikkerhed som deres mandlige medstuderende, til efter få måneder at være markant mindre sikre på sig selv. Til trods for at fysik som et naturvidenskabeligt fag gør meget for at tiltrække og fastholde kvinderne på studiet, er frafaldet stort, og selvværdet hos kvinderne lavt. Hasses pointe er, at kroppen som tegn på kønnet på forhånd diskvalificerer kvinderne i et miljø, hvor grundopfattelsen er, at mænd måske nok er usexede nørder, men tilgengæld har de høj faglighed. Kvinderne er alene i kraft af deres kurver som udgangspunkt sexede og derfor pr. definition ikke-faglige. Udgangspunktet for de to køn er forskelligt, og det spiller ind på selvværdet, hvilket får følger for de videre karrieremuligheder. Hasse er velskrivende, og man lader sig fange med i tankerækkerne. Modsætningerne er dog hårdt trukket op, og udfra tanken om den kritiske masse er det spørgsmålet, om pointerne fra fysikstudiet kan genfindes på studier, hvor der er markant flere kvindelige studerende? Det er interessant at lade Bloch og Hasse stå umiddelbart efter hinanden, da mange af pointerne fra Blochs tekst kan genfindes hos Catherine Hasse og synes at være med- virkende til de processer, Hasse analyserer.

Dorte Marie Søndergårds bidrag er af en helt anden karakter, hvilket netop er det, der gør bogen spændende, fordi de samme emner angribes på så forskellig vis. Hun tager udgangspunkt i det forhold, at universiteterne fremhæver sig selv som neutrale, idet eksistensberettigelsen i universitetet forudsættes at være fagligheden. Igennem en række interviews påviser hun, hvorledes mænd har lettere ved at lære sig spillereglerne og derfor fremstår som rigtige forskere i højere grad end kvinderne. Med køn som optik når hun frem til, at det bliver stadig sværere at tro på de videnskabelige kvalifikationer som neutrale og ufortolkede. At Søndergårds tekst står som et af de første indlæg er ikke tilfældigt, da der gentagne gange refereres til hendes tekst. Det ligger da også som en underliggende strøm at det tilsyneladende neutrale alligevel er stærkt kønnet, og netop ved ikke at acceptere det som kønnet, kommer kønnet til at virke endnu kraftigere.

Akademisk tilblivelse må nok i bund og grund siges ikke at tilføre særlig meget nyt. Ret beset fortæller den blot, at kun lidt har ændret sig. Dele af bidragene er endog omskrivninger af pointer, der har været brugt andetsteds. Alligevel virker bogen stærkt fordi sammensætningen af de enkelte bidrag er med til at forstærke budskaberne og med til at tegne et mangefacetteret billede af kønnet i akademia.
Kunne der ikke gives andre forklaringer end køn på de enkelte problemstillinger? Jo, det kunne der nok, men at bruge kønnet som optik for arbejdet i akademia synes fortsat at være meget oplagt - desværre.

\section{Esther Nørregaard- Nielsen \\ Sociologisk Institut \\ Københavns Universitet}

\section{R. W. Connell: Gen- der. Cambridge: Polity Press/Blackwell Publis- hers 2003 (173 sider, ISBN 07-456-2715-3).}

Den australske køns- og maskulinitetsforsker R. W. Connell giver med bogen Gender læseren indblik i det overblik, han har erhvervet sig gennem et langt forfatterskab. Bogen kan bedst karakteriseres som en introduktion til en bred humanistisk og samfundsvidenskabelig tilgang til køn. Den kommer med sine relativt få sider vidt omkring fra køn i det personlige liv til køn i det globale. Bogen er letlæselig og giver mange referencer til yderligere fordybelse. Således er den yderst anvendelig i undervisningssammenhæng inden for et bredt spektrum af fag på højere læreanstalter, der tilbyder introducerende kurser i sociale og kulturelle kønsaspekter. Og hvis ikke før, så sidder man efter endt læsning tilbage med det indtryk, at sådanne kurser burde alle uddannelsessteder udbyde.

Gender består af otte kapit- 
ler á 10-20 sider. Titlen kunne ikke være anderledes, idet kapitlerne handler om køn i alskens kulturelle og sociale sammenhænge. Efter et introducerende kapitel, der definerer køn og dokumenterer aktualiteten af køn, er kapitel to på pædagogisk vis en gennemgang af fire cases om, hvorledes køn dannes i henholdsvis skoler, miner, sex og krig. Kroppen er fokus i tredje kapitel, og kapitel fire analyserer kønsrelationer, herunder kønsdimensioner $\mathrm{i}$ magt-, produktions-, emotions- og symbolske relationer. Efter kapitel fem om det personlige liv, omfattende socialisation, identitetsdannelse og seksualitet, er bogens tre sidste kapitler mere "makro"-orienterede, omhandlende bl.a. virksomhedsmæssige og statslige forhold, forskellige sociale bevægelser samt politik i bred forstand.

Når Connell laver en traditionel kønsskillelinje mellem kvinder og mænd, er der nok af kønsforskelle at fremhæve. Statsoverhoveder, multimillionærer, mordere og våbenbesiddere er oftest mænd i denne forstand. Fx angives det, at fire ud af fem våbenejere i USA er mænd - selvom disse våben er anskaffet i selvforsvarsøjemed. Endvidere udgør kvindernes gennemsnitsindtægt på verdensplan kun 56 procent af mændenes. Og kønsstereotyper påpeges i rigt mål i de undersøgelser af massemedier, Connell refererer til.

Connell har blik for, at såvel kvinder som mænd er udsatte for restriktioner, men på forskellig vis i specifikke sammenhænge. Hvor kvinder oftest er udsat i porno, prostitution, religion og vittigheder(!), er alkoholmisbrugs- og ulykkesraterne højest for mænd. Som Connell skriver, kan en kønsorden ofte fastslås, hvorimod det kan knibe med at forklare og især gøre den videnskabeligt forståelig.

Selvom Connells utallige eksempler på kønsforskelle refererer til kvinder og mænd i traditionel biologisk forstand, indebærer hans definition af køn ikke, at de biologiske forskelle danner basis for de sociale processer. Omvendt definerer han køn som den struktur af sociale relationer, der er centreret omkring reproduktionssfæren, og de praktikker (styret af denne struktur), som fører reproduktive distinktioner mellem kroppe med ind i sociale processer (s.10). Kønsrelationer er således et kulturelt og socialt produkt, som er foranderligt og derfor også kan ophæves.

Denne tilgang til køn bliver eksemplificeret $i$ de fire cases i kapitel to, men bliver for alvor konkretiseret i kapitel tre i Connells afvisning af tre fremherskende kropsopfattelser. De tre "modeller": kroppen som maskine, kroppen som canvas (der kan aftrykkes tegn og symboler på) eller kroppen som to sfærer implicerer tre forståelser af køn, hvor henholdsvis det sociale reduceres til det biologiske, det biologiske reduceres til det sociale eller i den tredje model bliver skilt ad i krop og sjæl, med de to termer "sex" og "gender" til følge. En tilgang, der betragter kroppen som en "krops-refleksiv praksis", hvor kroppen både er handlende og objekt, finder Connell derimod er i overensstemmelse med det kønsperspektiv, der ligger til grund for bogen. I dette perspektiv kan kroppe formes og køn skabes, men konstruktionsprocessen kan udmærket støde på grænser. Connell nævner nogle eksempler fra sin bog The Men and the Boys (2000), hvor kroppe yder modstand og ikke blot er genstand for enten biologiske eller sociale tvangsprocesser.

Det tydeliggøres imidlertid ikke i bogen, hvor det er, og hvordan konstruktioner af køn støder på grænser. Connell udviser stor opmærksomhed omkring, hvorledes køn formes og kønsrelationer ændrer sig i tid og rum, hvilket både er informativt og inspirerende. Til gengæld virker den ellers sympatiske pointe med den genstridige krop og hermed hele forståelsen af køn underligt uforløst. Forestillingen om en i psykoanalytisk forstand "dybere" / ubevidst kønsforskel afviser Connell som en myte (s. 43). Specifik adfærd og i visse tilfælde udseende synes heller ikke at følge individets kromosomsammensætning. Men Connell opererer med en kroppens "materialitet" (s. 48), han anskueliggør i følgende kausalkæde: social-biologisksocial. Det biologiske skal betragtes som indkapslet i det sociale, og således vil adfærd, holdninger, intelligens m.m. m. ikke skille ved det tradi- 
tionelt biologisk bestemte køn, hvilket han dokumenterer ved henvisninger til en række undersøgelser.

I kraft af sit tilnærmelsesvist globale overblik over kønsstudier er Connell i stand til konstant at give eksempler og referere til undersøgelser, der ikke blot kan skitsere kønsforskningens bredde, men også dokumentere, hvorledes den efterhånden er rodfæstet og veletab- leret i mange miljøer rundt om i verden. Det skal dog bemærkes, at den skandinaviske kønsforskning ikke har ind prentet sig synderligt $\mathrm{i}$ refleksionerne fra "down under". I det hele taget bærer bogen - skønt sin intention om at bidrage med et globalt perspektiv på køn præg af en angelsaksisk skævvridning i sine referencer til kønsforskere. Connell medgiver i forordet, at han kun behersker få europæiske sprog, men da de fleste højtestimerede kønsforskere også har publiceret på engelsk, er der ingen undskyldning for næsten udelukkende at strø referencer ud til amerikanske, engelske og australske kønsforskere.

Inge Kryger Pedersen

Sociologisk Institut

Københavns Universitet 